\section{BA Institute of \\ YK Business Administration \\ 六下 \\ Karachi \\ Leadership and Ideas for Tomorrow}

Business Review

Volume 14 Issue 2 July-December 2019

7-1-2019

\title{
Entrepreneurial cognition process within a hostile business environment: A research study of high, medium and low performing entrepreneurs of Pakistan
}

\author{
Mohammad Asad Ilyas \\ Institute of Business Administration, Karachi, Pakistan \\ Severine Le Loarne \\ Grenoble Ecole De Management, France \\ Wajid Hussain Rizvi \\ Institute of Business Administration, Karachi, Pakistan
}

Follow this and additional works at: https://ir.iba.edu.pk/businessreview

\section{(c) (9)}

This work is licensed under a Creative Commons Attribution 4.0 International License.

\section{Recommended Citation}

Ilyas, M. A., Loarne, S. L., \& Rizvi, W. H. (2019). Entrepreneurial cognition process within a hostile business environment: A research study of high, medium and low performing entrepreneurs of Pakistan. Business Review, 14(2), 92-115. Retrieved from https://doi.org/10.54784/1990-6587.1019 


\title{
Entrepreneurial cognition process within a hostile business environment: A research study of high, medium and low performing entrepreneurs of Pakistan
}

\author{
Mohammad Asad Ilyas • \\ Severine Le Loarne • Wajid Hussain Rizvi
}

\begin{abstract}
This research qualitatively observes and documents the influence of environmental hostility on entrepreneurial cognition at the firm level and how it influences strategy formulation to determine performance in the short and long run. The entrepreneurs have been categorized as high performers, medium performers and low performers and the performance of the entrepreneur is equated to the performance of his/her firm while maintaining focus on the entrepreneur. The results suggest that for all entrepreneurs, terrorism and violence were major elements of a hostile business environment. Different strategies devised by these entrepreneurs to cope with such a situation include work force development, succession planning, conceiving problems as solvable, setting the long term vision for the company and avoiding distractions.
\end{abstract}

Keywords Entrepreneurship · Hostile business environment · Business strategy $\cdot$ Cognition process

\section{Introduction}

Entrepreneurial activity is an important driver of economic growth within a country. Alternatively, a society's growth influences the entrepreneurial activity in the economy. For a society that experiences rapid expansion, entrepreneurial activity is high (Acs and Audretsch 2006). Societies with unstable environmental factors that lead to high risk, such as terrorism, have blurred entrepreneurial focus and decreased entrepreneurial activities.

For this study, the researchers examined 15 entrepreneurs to understand

Mohammad Asad Ilyas

Institute of Business Administration, University Road, Karachi-Pakistan

E-mail: ailyas@iba.edu.pk

Severine Le Loarne

Grenoble Ecole De Management, France

Wajid Hussain Rizvi

Institute of Business Administration, University Road, Karachi-Pakistan 
their strategic motivations and adaptations in response to environmental hostility. The businesses included firms from the manufacturing sector such as textile, retail, wholesale, food, construction and consumer items. By focusing on different industries, the researchers determined and identified common trends in the individual strategies of these firms devised by the entrepreneur. The researchers analyzed the overall perspective to understand business strategies in response to hostile environments.

The researchers selected five high performing entrepreneurs, five medium performers and five low performers for this study. The criterion to classify these companies as high performers was a revenue growth rate above $20 \%$ on an annual basis. Entrepreneurs of medium performing companies had revenue growth rate between $-20 \%$ to $20 \%$ on an annual basis. Entrepreneurs of low performing companies had a negative revenue growth rate of $-20 \%$ and were shutdown/on the verge of shutting down.

A key emerging element, i.e. terrorism and violence, has been identified in this study as an important feature of hostile business environment along with dynamism, heterogeneity, uncertainty, intense competition, regulatory landscape and political and economic instability. The effects of terrorism on social and political structures is poorly understood (Shrivastava 2005). Poor infrastructure (law, politics, and education), failure of organizations (NGOs, corporations, government organizations), high unemployment, and a rising crime rate create vacuums for terrorist organizations to infiltrate at the local level (Shrivastava 2005). However, there is dearth of literature in establishing the impact of terrorism and violence on the cognitive process of entrepreneurs.

The primary objective of this research is to examine and identify basic strategies deployed by entrepreneurs in Pakistan in order to deal with hostility in the business environment. In particular, this study highlights the connection between the entrepreneur's cognition process and response strategies devised in a hostile business environment. The categorization of high, medium and low performance is based on observation of firm performance. The research highlights entrepreneurs'/managers' response to external uncontrollable environment (terrorism, violence or political instability etc.), the impact of external environment on business activity and sustainable strategies to combat these hindrances.

This research aims to fill this gap and contribute to the current literature on hostile business environments, entrepreneurial cognition process and specific business strategies of entrepreneurs to counter the hostility of the business environment. Findings and conclusions drawn from this research effort can be used as a starting point to improve long run business strategies and macro level policies for prosperous business growth.

\section{Literature review}

Literature views environmental hostility for businesses in terms of increased competition, political and economic instability, dynamism, heterogeneity, uncertainty, and threat to organizational goals (Brews and Purohit 2007; Courtney et al 1997; Khandwalla 1972; Lawton et al 2012; Miller and Friesen 1983; 
Torkkeli et al 2012). Developing countries, such as Pakistan, experience internal governance issues and environmental hostility for businesses and entrepreneurial ventures in the form of violent crimes and terrorism.

\subsection{Business environment}

The concept of business environment is very complex and different scholars have explained this concept in different ways (Eruemegbe 2015). Business environment has been described as a phenomenon that is complex and varied enough to be captured and explained by any one definition (Adeoye and Elegunde 2012). There are different types of environmental factors that affect a firm's performance, depending on its size and the industry in which it operates (Adeoye and Elegunde 2012).

Bandura (1999) explained social cognitive theory as an agentic perspective; the environment is not a monolithic force and there are three types of environment: (a) imposed; (b) selected; and (c) constructed. In each of the environments, the potentiality exists to have some leeway and exercise control over it.

\subsection{Hostile business environment}

Under a hostile business environment, intensity of competition puts a lot of pressure on a firm, its behavior and operations (Lindelöf and Löfsten 2006). Covin and Slevin (1989) describe intense competition as a major characteristic of hostile environment. Some firms try to use uncertainty to shake out and unsettle their competitors (Wernerfelt and Karnani 1987). Kotey et al (2014) categorized hostility as an environmental variable, like dynamism and heterogeneity; it is the vigor and intensity of competition and the variability in the industry. Dynamism is the rate of change and innovation in the industry along with the unpredictability of competitor and customer behavior; heterogeneity is product and market diversity (Miller and Friesen 1983). These may be aspects of a hostile business environment as well. An example of a hostile environment is the 2008 economic crash, which had traits of high-risk, declining markets, and unstable external conditions (Lawton et al 2012).

Environmental hostility is part of the dynamism dimension, and encompasses hostilities relating to a firm's interaction with customers, competitors, and the technological and regulatory environments in which the business operates (Torkkeli et al 2012). However, some literature differentiates dynamism (instability and uncertainty) and hostility (competition for resources) from each other (Campos et al 2015). Based on studies by Acs and Audretsch (2006); Goktan and Gunay (2011); Steensma et al (2000), the researchers deduced that the entrepreneurial focus becomes distracted or risk averse when instability in the environment goes up.

Bingham et al (2011) have found that regulatory pressure increases dynamism in the business environment. Ambiguity in the regulatory regime may result in uncertainty in the business environment causing decline in entrepreneurial 
growth and development (Zhang 2010). Adomako and Danso (2014) maintain that firm's performance is adversely effected by weak and underdeveloped regulatory environment.

\subsection{Terrorism and violence}

Since September 11, 2001, acts of terrorism have increased enough to influence the social structure of society (Shrivastava 2005). This is true for all countries at all levels of societal operations. The most damage a terrorist activity can inflict on businesses and societies is not just through bombing or killing; rather, it is through kidnapping. Acts of kidnappings create a hostile environment for the entire society. No one feels safe, but it generates money in the form of ransom and attracts free publicity (Prieto-Rodríguez et al 2009). Mass killings do not create as much public fear as kidnappings and variable armed attacks (PrietoRodríguez et al 2009). Acts or threats of terrorism generate political and economic instability and adversely affect growth rates and GDP (Haj-Yehia 2003).

Variables of a hostile environment in mainstream literature include economic and financial variables oriented towards the customers, product, business innovation, and competition. Research literature on terrorism is still in developmental stages. However, there is some subject matter available on this topic. Abadie and Gardeazabal (2008) argued that terrorism adds to uncertainty in the business environment and reduces the ROI. Increased terrorism may result in movement of capital across countries and reduction in foreign direct investment in regions with terrorist activity.

\subsection{Entrepreneurial cognition process}

Entrepreneurship is an important economic driver in society. According to Wong et al (2005), entrepreneurs bring change and new ideas to the market and fuel socioeconomic growth. However, entrepreneurship is not merely an organizational role; it is a personality trait, an individual's approach towards businesses. Entrepreneurs have been described as risk-takers, proactive, innovative and aggressive and all of these characteristics are part and parcel to survive and grow in a hostile business environment. Big businesses and firms are the brainchild of an entrepreneurial mindset and effort.

When a firm is in a hostile environment, entrepreneurial orientation contributes to greater performance (Lindelöf and Löfsten 2006). There is a strong correlation between environmental hostility and entrepreneurial orientation (Miller and Friesen 1983). Entrepreneurs shape business strategies that influence the macro environment (Peng 2001). Past researchers acknowledged the impact of entrepreneurial cognition, but failed to grasp the core entrepreneurial traits that make strategic planning possible and viable or address how those traits influence entrepreneurial cognition in response to a hostile business environment. This research fills this gap by identifying the strategies entrepreneurs utilize in hostile environments.

Popescu (2014) and Mitchell et al (2002) explained that entrepreneurial 
traits are no guarantee of automatic success. A study by Miller and Friesen (1983) suggests that strategy making must be right for the environment; to study entrepreneurial cognition, researchers should not study why an entrepreneur selected a strategy (cognition) but study the cognitive process that resulted in the entrepreneur's effectual framing of the task and subsequent inclusion of that in a set of alternative responses to a decision task.

\subsection{Business strategies}

Khandwalla (1972) demonstrated that dynamic, hostile, and heterogeneous environments require more structural uncertainty reduction, differentiation, and integration. For structural uncertainty reduction, firms develop strategies over time to counter variables within the hostile environment and organically mitigate specific variables. When the environment becomes uncertain and turbulent, firms become more market oriented by implementing different marketing activities to understand the needs of customers (Davis et al 1991). According to Arieftiara et al (2017), the best strategy is the one that is the most suitable given the external environmental conditions that a firm faces.

\subsection{Gaps in literature}

This study builds upon the systematic gap in literature that calls for in-depth micro-level study to observe and document the phenomenon of strategy making in a hostile business environment. The characteristics of a hostile business environment have been defined ambiguously in literature (Campos et al 2015; Torkkeli et al 2012; Vagnoni and Khoddami 2016). An important element i.e. terrorism and violence also seems to be missing from the literature of hostile business environment. Business strategies that exist in literature are too generic to be applied specifically to hostile business environments and are from the perspectives of large businesses and firms (Ansoff 1987; Covin and Slevin 1989). From an entrepreneurial perspective, literature's thrust is towards documenting the traits of entrepreneurs rather than understanding the interplay of business environment and cognition process (Gartner 1989). There is also a contradicting opinion on the issue whether hostile business environment results in lack of opportunities or presents more opportunities for exploitation (Covin and Slevin 1989; Hall 1980).

The literature review suggests that there is a need for observation and documentation of the entrepreneurial cognition process in a hostile business environment and its effect/outcome through firm performance (Adomako and Danso 2014). Literature has general business strategies scanning the external environment, agility of the firm, and swift responsiveness of the firm etc. However, it is not specific in defining the hostile environment and business strategies to counter the hostile environment. Researchers also seem to be defining the business environment ambiguously and narrowly. Researchers defined hostility in similar ways in the available literature, but there is no consensus as to what variables induced hostility in the business environment. Hostile situations are 
dynamic and complex (Brews and Purohit 2007; Courtney et al 1997). However, these definitions are restrictive and do not fully encapsulate the essence of hostility as experienced in modern times by real-world business organizations.

There are various other factors (e.g. terrorism and violence) that induce hostility in the environment by obstructing business activities and discouraging investments. These contemporary variables (terrorism and violence) are absent from existing literature, but are at the forefront of developing economies and affect the routine business activity by obstructing operations at a micro level. There is little literature available on these factors and this has been identified as a major gap in literature which this study aims to contribute towards. Brews and Purohit (2007); Courtney et al (1997); Miller and Friesen (1983); Lawton et al (2012); Khandwalla (1972); Torkkeli et al (2012) defined hostile environment according to variables that affect businesses; they did not include terrorism and violent crimes that affect people who run businesses. Based on the literature, the researcher proposed that terrorism/violent crimes is a variable of the hostile environment and has an effect on the entrepreneurial cognition process. The conceptualization of the hostile environment by the entrepreneurs confirmed this proposed gap.

\section{Methodology}

The basis of this research is the interplay of environment, entrepreneurial cognition process, and the formulation of business strategies according to social cognition theory (Bandura 2012). This model situates human functioning within interpersonal influences, behaviors, and environmental forces. Researchers conducted a qualitative exploratory research with 'a three research studies design' consisting of five entrepreneurs in each category. Difference among the categories is the success level of the entrepreneur. Category A observes the cognition process of high performing entrepreneurs, Category B observes the cognition process of medium performing entrepreneurs and Category $\mathrm{C}$ observes the cognition process of failed or low performing entrepreneurs. Performance of the entrepreneur is connected with the performance of the firm but the focus of the observation remains on the entrepreneurs.

The criterion to classify these companies as high performers was a revenue growth rate above $20 \%$ on an annual basis. Entrepreneurs of medium performing companies had a revenue growth rate between $-20 \%$ to $20 \%$ on an annual basis. The criteria to classify companies as low performers was their negative revenue growth rate, which was less than $-20 \%$ on an annual basis. Another criterion for these companies was that they were already closed or were very close to being closed.

The data collected from semi-guided interviews, documents provided by the entrepreneurs related to their firm performance and researcher observations. The researchers identified variables and finalized figures for each field of study (environment, entrepreneurial cognition, and business strategies) and proposed theoretical framework. The researchers then constructed through the theoretical framework mind map of codes after the pilot study and suggested that these 
fields of study affect each other according to the theoretical framework. This study examined the interplay of these fields and their effects on the outcome (firm performance).

In the absence of any substantive research related to hostile environments and business strategies, the need for a study at firm level to observe and document this phenomenon is apparent. The researchers observed a hostile environment setting, where terrorism and violence were prevalent, and its effects on the business community and their responses. The study was divided into three areas of inquiry:

- What exactly is a hostile environment for entrepreneurs?

- What is the cognition process of an entrepreneur within a hostile environment?

- What business strategies (responses) do entrepreneurs develop in a hostile environment after experiencing terrorism or violence?

\section{Results}

The focus of this study was on the observation and documentation of the entrepreneurial cognition process within the hostile environment and the subsequent actions (business strategies). In this section, the high performers, medium performers, and low performers are summarized and compared. The main themes in this section are as follows:

1. Conceptualization of the hostile business environment

- Terrorism and violent crimes

- Regulatory environment

2. The entrepreneurial cognition process

- Entrepreneurial focus

- Self-efficacy

- Appraisal of the situation

3. Business strategies

4.1 Conceptualization of the hostile business environment

\subsubsection{High performers}

All high performing entrepreneurs experienced violent crimes at a personal level due to deteriorating law and order conditions in Pakistan. Entrepreneur E of Company E experienced a kidnapping attempt. Entrepreneur C of Company C negotiated with kidnappers for the release of his company's managing director. Entrepreneur D of Company D experienced the stress of having his brotherin-law kidnapped. Entrepreneur A experienced similar violent crimes related to violent gangs and strikes. Entrepreneur B2 of Company B was the victim of an illegal arrest.

Despite experiencing these crimes on a personal level, the businessmen claimed that the weak regulatory landscape of the country was the biggest challenge for 
their businesses. Company $\mathrm{C}$, for example, did not get its licenses on time. The license went to partners of different ministers. This delayed their production and directly impacted the company's growth. Company B experienced tax raids by the FBR despite being a law abiding and tax paying corporate citizen. Entrepreneur A faced bureaucratic issues in getting the land for his factory, and eventually paid heavy bribes to close the deal. He blamed lack of governance in the country for delayed business success. Entrepreneur E bluntly blamed corruption and terrorism within the government system for the deteriorating industry conditions. All entrepreneurs strongly believed that issues of regulation could be resolved by improving the state of governmental agencies. Entrepreneur A of Company A said that the country is waiting for a good leader to fix the issues. However, all the businessmen also believed that it is the regulators who are direct beneficiaries of the weak regulatory environment and there is little incentive for them to resolve the issue.

Business hostility impacts industries in different ways. Company B experi-

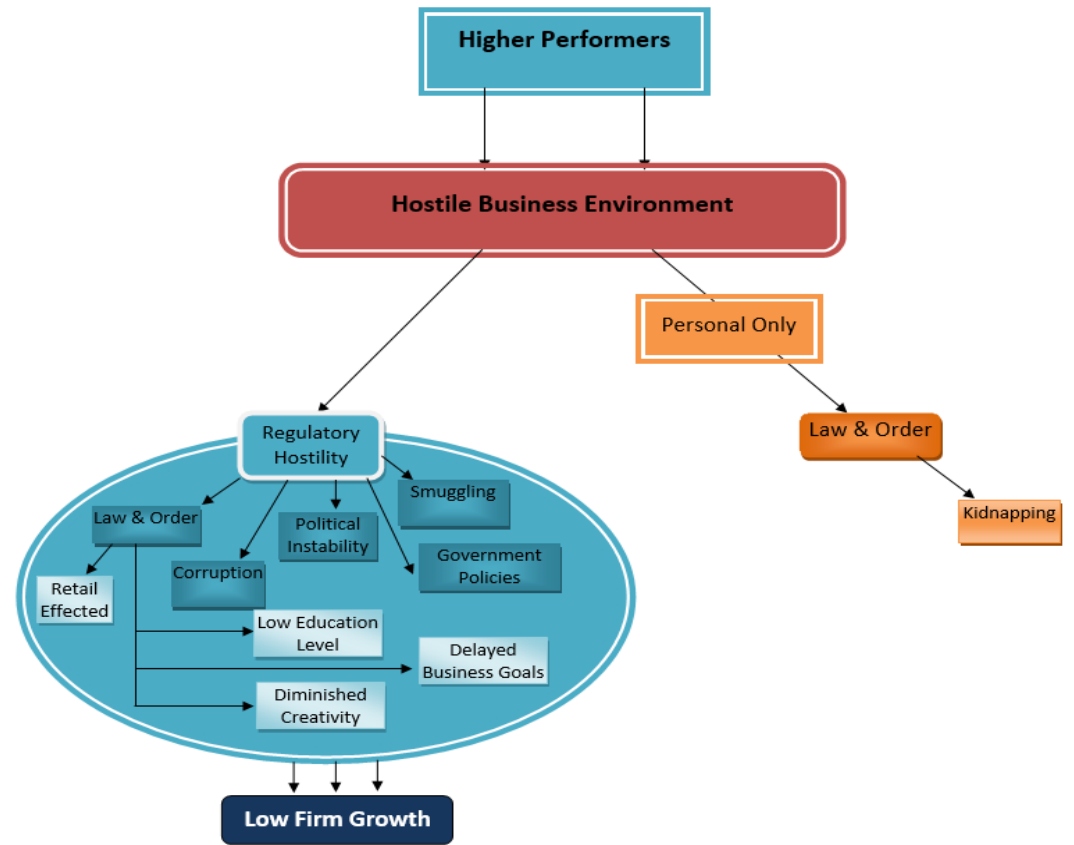

Fig. 1: Hostile business environment conceptualized-High performers

enced a slump in its retail business. Sales decreased with political unrest in the country and due to poor law and order. Similarly, Company C and Company A struggled to accomplish their business goals due to the weak regulatory environment. For Company D, the weak regulations impacted its expansion planning due to dearth of competent HR. Business hostility hampered Entrepreneur E's business succession planning; he did not want to involve his own children in the business because of the threatening environment and failed to groom a poten- 
tial successor to continue the business. This led to a definite threat to business survivability.

\subsubsection{Medium performers}

Medium performing entrepreneurs were victims of deteriorating law and order conditions. They experienced terrorism and violent crimes at a personal level. Mr. Hussain experienced the kidnapping of close family members (his wife, mother-in-law, and son). He also routinely received extortion calls. Mustafa Rahman was shot at, either intentionally or randomly. Entrepreneur F experienced robbery of valuable raw materials in his factory. He also observed incidents of kidnappings in his close social circle. Entrepreneur $\mathrm{H}$ experienced personal dealings and negotiations with the water tanker mafia, which shut off legal water connections to his factory. Entrepreneur I was a frequent victim of mobile snatching. These violent crimes and hostility in the environment put these entrepreneurs in constant states of stress and fear, pressuring them into shifting focus from their business goals and vision.

Businessmen from this category also faced challenges in the regulatory landscape, primarily issues with tax collecting agencies. Entrepreneur J was given a $40 \%$ tax on raw material by customs because he imports it. Entrepreneur $\mathrm{H}$ and Entrepreneur I had high capital stuck in the refund cycle with tax agencies, which led to debt. Businessmen pay $30 \%$ of the refunds as bribes to get the money out of the tax cycle. Mr. Hussain received frequent notices from the tax agencies that made him lose focus. Entrepreneur F was under stress due to 32 governmental agencies under the same aspect of regulations. However, Entrepreneur $\mathrm{H}$ believed that these agencies have high levels of corruption running through them, which leads the businessmen to distrust them, ignore the criminal activities, and take precautionary measures at a personal level. Moreover, all entrepreneurs also blamed the weak regulatory landscape and a weak implementation of government policies. An example is an influx of Chinese products in the market that damages the sales of the local industry.

These factors result in an increased per-unit cost that causes businesses to fall into debt. Entrepreneur $\mathrm{H}$ said that the increased debt is passed on to the consumer as higher prices to cover the expense of production. Lack of governmental infrastructure, such as electricity and gas shortages, also contribute to incremental unit price increases. Businesses face a decline in their productivity due to a lack of focus on business goals and activities, according to Mr. Hussain and Mustafa Rahman. Mustafa Rahman, delayed business goals for two years because of the environmental hostility. To further aggravate the matter, businesses also face the issue of low quality products, as confirmed by Mr. Hussain who employed minimal quality checks on his product. This lack of focus and creativity results from a continued state of stress caused by a hostile business environment. Despite this, all entrepreneurs trained their children to join the business as successors. This shows their attention to succession planning. This was true for all except Entrepreneur F, who discouraged his son from entering the business because of the increased hostility in the environment. 


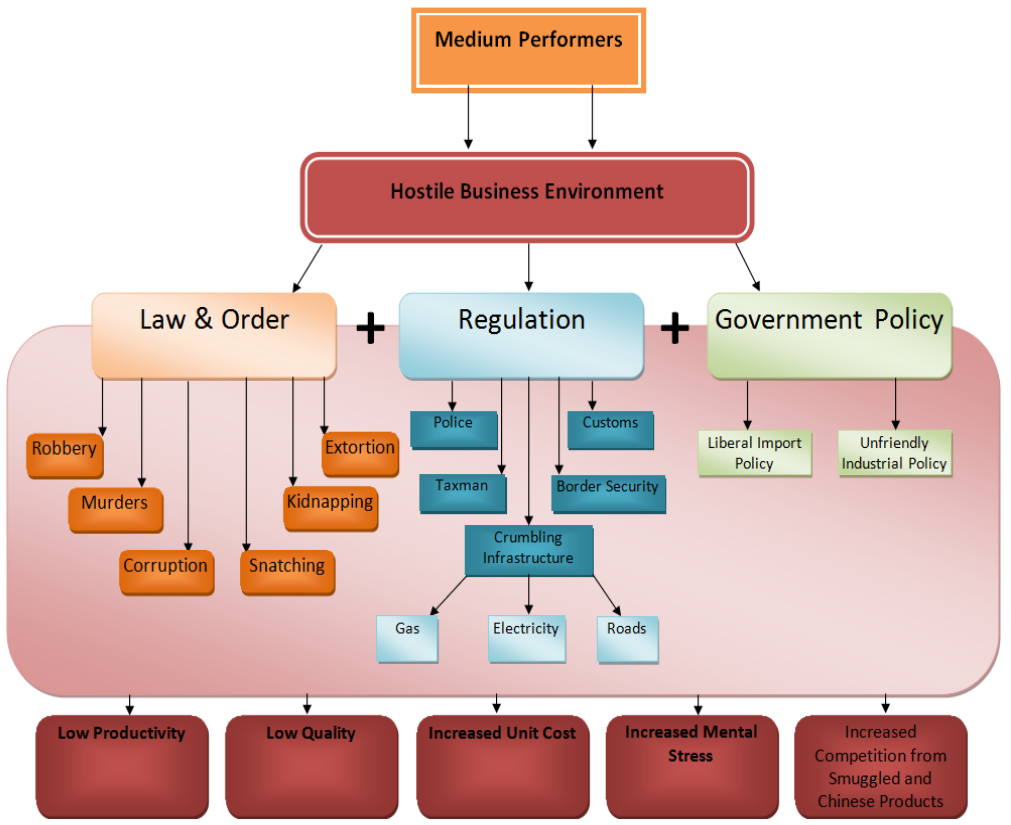

Fig. 2: Hostile business environment conceptualized-Medium performers

\subsubsection{Low performers}

Low performers faced environmental hostility in the form of terrorism and violent crimes at a personal level and were the victims of snatching and robbery. Environmental hostility also encompasses strikes, political uncertainty, gang wars and ethnic clashes.

In addition to violent crimes and terrorism, these businesses also blame governmental agencies and policies for creating business hostility. The FBR pestered Entrepreneur $\mathrm{K}$ for undue tax audits. He paid an extortion fee to get out of the legal spiral. Entrepreneur L also blamed the government for lack of support through weak policies and low trade barriers. He stated that this led to increased competition in raw materials and final products. His business was unable to succeed because of the increased competition from low cost Chinese products. Entrepreneur N lamented about the increased competition from India because of low trade barriers, which led to his products' higher costs.

Entrepreneur O, Entrepreneur M and Entrepreneur N closed their businesses due to business hostility. They feared for their lives all the time. Similarly, businesses such as Company $\mathrm{K}$ and Company L are close to shutting down because of the same situation. Entrepreneur K, who is relatively successful in his business, wants to close his business and move to Punjab where he perceives the business environment to be friendlier and less hostile.

Business Review: (2019) 14(2):92-115 


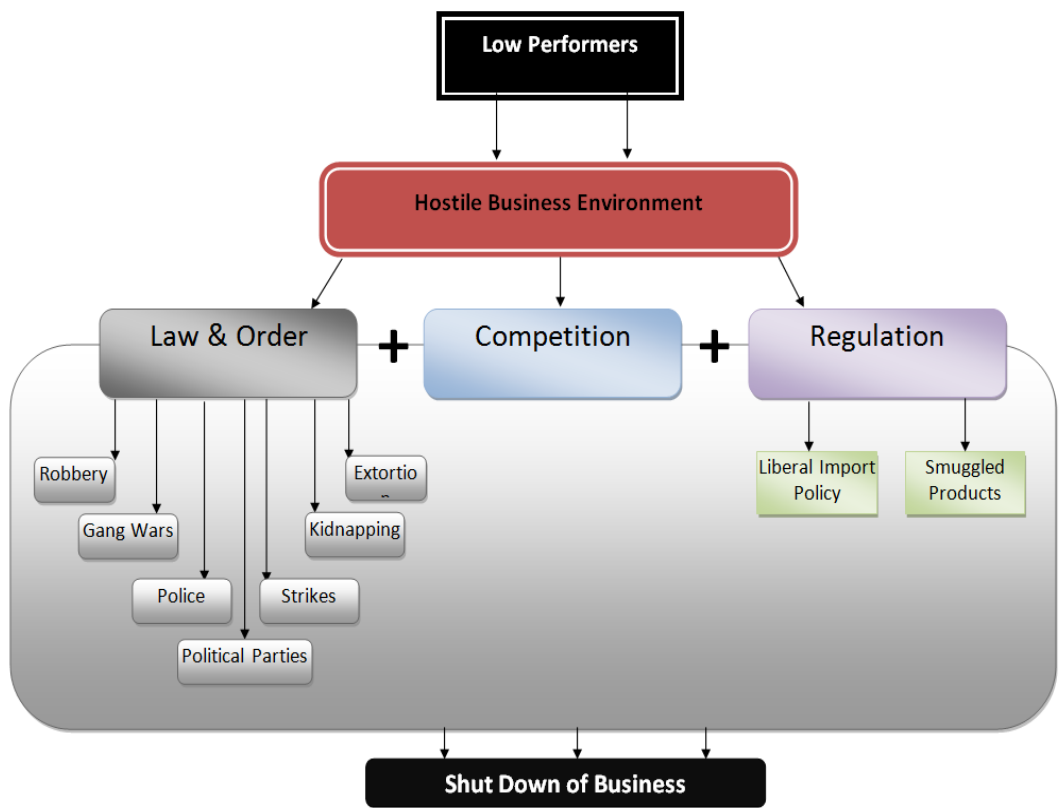

Fig. 3: Hostile business environment conceptualized-Low performers

\subsubsection{Analysis}

High performing firms and businesses face challenges of business hostility due to the weak regulatory landscape. Weak regulation manifests in corruption within the administrative systems of the government, lack of governance, political instability and incompetent governmental policies. Business managers face terrorism and violent crimes at a personal level, but are undeterred in their focus on business goals. They believe that the regulatory landscape can improve through improved government. Medium performers face business hostility through terrorism and violent crimes at a personal level and through an unfriendly regulatory landscape. These entrepreneurs are under a constant state of stress that causes blurred business vision and loss of focus towards business goals. Poor performers face business hostility through violent crimes and terrorism at a personal level, but with higher intensity. These businessmen are unable to survive, because they have no plans for expansion or growth and shut down because of environmental hostility.

\subsection{Entrepreneurial cognition process}

In the following section, the researcher will narrate the cognitive processes of the three categories of performers. As studied in the three categories, each has their own appraisal of the situation, fear, and hopes for their businesses within the hostile environment. 


\subsubsection{Focus and self-efficacy}

The researcher documents each entrepreneur's conceptualization of self-efficacy and focus within the hostile business environment.

- High performers

Entrepreneurs in this category are highly focused on business activities and goals despite the level of business hostility they face due to the weak regulatory landscape. Company A focused on business growth by developing a workforce and maintaining/enhancing quality standards. Company B focused on growth by creating international expansion plans, maintaining quality, and developing customer relationships. Company $\mathrm{C}$ strived for growth by focusing on R\&D. Company D focused on maintaining the current level of growth through quality products and good vendor relationships to ensure that there is no decline in the business. Company E focused on maintaining and sustaining the current level of business operations.

Self-efficacy of the entrepreneurs influences their business focus. All entrepreneurs in this category had a high level of self-efficacy. Entrepreneur A felt that nothing is unmanageable, all problems can be resolved. Similarly, Entrepreneur D felt that all problems, except death, are manageable; everything has a solution. Entrepreneur E believed in his hard work and felt assured that it could solve all problems. He stated that there is no reason not to rely on hope with hard work as an ally.

This positive outlook drives these businessmen to continuously grow their businesses and attain their goals. Entrepreneur B2 of Company B was confident that the business goals of the company remained unaffected by the threatening regulatory force of the FBR. Entrepreneur C similarly noted opportunities in the hostile environment and has future expansionary plans. His confidence and past experiences gave him the drive to excel further.

Table 1: Entrepreneurial cognition process (Focus \& Self-efficacy)-High performers

\begin{tabular}{cllccc}
\hline$\#$ & Company & Proposition variable & Presence & Proposition variable & Presence \\
\hline 1 & Company A & Entrepreneurial focus & $\mathrm{Y}$ & Self efficacy & $\mathrm{Y}$ \\
2 & Company B & Entrepreneurial focus & $\mathrm{Y}$ & Self efficacy & $\mathrm{Y}$ \\
3 & Company C & Entrepreneurial focus & $\mathrm{Y}$ & Self efficacy & $\mathrm{Y}$ \\
4 & Company D & Entrepreneurial focus & $\mathrm{Y}$ & Self efficacy & $\mathrm{Y}$ \\
5 & Company E & Entrepreneurial focus & $\mathrm{Y}$ & Self efficacy & $\mathrm{N}$ \\
\hline
\end{tabular}

\section{- Medium performers}

Medium performing companies have a blurred focus on business goals because of business hostility. Entrepreneur F was unable to define business goals, which resulted in negative growth for his business. Similarly, Entrepreneur G was unable to focus on business growth because he was unsure of his business' viability in the current situation. Entrepreneur I lost focus on growth and delayed projects and expansionary plans because of hostility. Entrepreneur $\mathrm{H}$ was unable to maintain a singular focus on company operations because of business hostility, which 
slowed his business growth. Entrepreneur J experienced the same loss in focus because of business hostility, which hampered his business growth and led to stagnancy in the business.

Despite the lack of focus, these entrepreneurs displayed a high level of selfefficacy. Entrepreneur J decided to enter a business that had previously failed, and introduced a new product that had no predictor. Entrepreneur $\mathrm{H}$ hoped for growth of his company within the next five years despite the current negative growth, because he believed that the company's systems and internal infrastructure were correct. Entrepreneur G continued to be an important industrial player motivated by his drive for attaining excellence in the field of motor parts. Entrepreneur I recently recovered from a factory fire. He believed his experience, vendor connections and industry knowledge would help him move forward and reestablish his business. Entrepreneur F displayed low self efficacy through his inactivity in helping his company revive from low sales and revenue growth.

Table 2: Entrepreneurial cognition process (Focus \& Self-efficacy)-Medium performers

\begin{tabular}{cllccc}
\hline$\#$ & Company & Proposition variable & Presence & Proposition Variable & Presence \\
\hline 1 & Company F & Entrepreneurial focus & $\mathrm{N}$ & Self efficacy & $\mathrm{N}$ \\
2 & Company G & Entrepreneurial focus & $\mathrm{N}$ & Self efficacy & $\mathrm{Y}$ \\
3 & Company H & Entrepreneurial focus & $\mathrm{N}$ & Self efficacy & $\mathrm{Y}$ \\
4 & Company I & Entrepreneurial focus & $\mathrm{N}$ & Self efficacy & $\mathrm{Y}$ \\
5 & Company J & Entrepreneurial focus & $\mathrm{N}$ & Self efficacy & $\mathrm{Y}$ \\
\hline
\end{tabular}

- Low performers

Low performing entrepreneurs were close to shutting down their businesses or already shut them down because of business hostility that led to a continual mental strain and stress for them. This mental strain had led to a complete lack of focus for these entrepreneurs. Entrepreneur M shut down his tea processing factory and is close to shutting down his business because of business hostility. Entrepreneur L was always under mental stress, and did not plan to expand his business with more investments. Instead, he will invest in the real estate business. Mr. Salami, despite performing well, wants to relocate to Punjab to have peace of mind. Entrepreneur $\mathrm{N}$ and Entrepreneur $\mathrm{O}$ shut their business down because of the mental stress the hostile environment created.

Low performers had low level of self-efficacy and hence lack of focus. However, they didn't take responsibility of failure and blamed external factors and setbacks for poor performance. Entrepreneur M extended credit for his past success to God and his family. Similarly, Entrepreneur L did not believe that his business could grow more. Entrepreneur $\mathrm{N}$ blamed the government and unethical industrial practices that hindered his company's growth. Entrepreneur $\mathrm{O}$ shut his business down because he believed he had no control over his commodity, which was also subject to external smuggling and internal oligopoly.

- Analysis

High performing companies have entrepreneurs with high levels of attention to maintaining business focus, driven by a willingness for business growth. This 
Entrepreneurial cognition process ...

Table 3: Entrepreneurial cognition process (Focus \& Self-efficacy)-Low performers

\begin{tabular}{cllccc}
\hline$\#$ & Company & Proposition Variable & Presence & Proposition Variable & Presence \\
\hline 1 & Company K & Entrepreneurial focus & $\mathrm{N}$ & Self efficacy & $\mathrm{N}$ \\
2 & Company L & Entrepreneurial focus & $\mathrm{N}$ & Self efficacy & $\mathrm{N}$ \\
3 & Company M & Entrepreneurial focus & $\mathrm{N}$ & Self efficacy & $\mathrm{N}$ \\
4 & Company N & Entrepreneurial focus & $\mathrm{N}$ & Self efficacy & $\mathrm{N}$ \\
5 & Company O & Entrepreneurial focus & $\mathrm{N}$ & Self efficacy & $\mathrm{N}$ \\
\hline
\end{tabular}

business focus results from the entrepreneurs' self-efficacy levels. All high performing entrepreneurs, other than Entrepreneur E, displayed a high level of self-efficacy, which facilitated maintenance of focus. Lack of self-efficacy in case of Entrepreneur E demonstrated that businesses suffer from declines in growth levels. Medium performers exhibited a lack of focus in their business goals because of environmental hostility and lower levels of self-efficacy, except for Entrepreneur F. Entrepreneur F displayed higher levels of self-efficacy that helped him develop business focus for the future and enabled him to drive his business towards success.

Poor performing companies all displayed a lack of focus because of business hostility and low levels of self-efficacy. These factors hindered vision formulation and strategy development, leading the entrepreneurs to minimally sustain business operations or close the business down due to increasing business hostility.

\subsubsection{Appraisal of events with high control potential}

- High performers

Four of the five high performing entrepreneurs appraised events as having high control potential, which gave them hope and allowed them to put in energies towards planning and strategizing for the future. Entrepreneur D believed that Pakistan is the best place to run his business despite the hostility. He devised solutions to mitigate the risks posed by environmental hostility because he is optimistic about the prospects and willing to stay in the country. Similarly, Entrepreneur A assessed the business hostility in the environment and hired the relevant workforce to deal with it and continue operations in the country.

Entrepreneur $\mathrm{C}$ noted the huge consumer market of the country and his confidence in the company's R\&D, which he believes will help them acquire a higher target audience. Entrepreneur B2 noted huge potential in the lawn retail business in Pakistan despite the hostile business environment. He will continue to expand the business in the country, brushing off Chinese competition as negligible in the process. In contrast to all these entrepreneurs, Entrepreneur E negatively appraised the situation; his only motivation for work is to ensure the continuity of routine operations.

- Medium performers

Two out of three medium performing entrepreneurs appraised events as having high control potential; the remaining three appraised them negatively. Entrepreneur $\mathrm{J}$ appraised the situation positively, and believes that the company can succeed locally and globally through continuous efforts. Similarly,

Business Review: (2019) 14(2):92-115 
M. Ilyas et al

Table 4: Entrepreneurial appraisal summary-High performers

\begin{tabular}{ccccc}
\hline \# & Company & $\begin{array}{l}\text { High control } \\
\text { potential }\end{array}$ & Hope & Fear \\
\hline 1 & Company A & $\mathrm{Y}$ & $\mathrm{Y}$ & $\mathrm{N}$ \\
2 & Company B & $\mathrm{Y}$ & $\mathrm{Y}$ & $\mathrm{N}$ \\
3 & Company C & $\mathrm{Y}$ & $\mathrm{Y}$ & $\mathrm{N}$ \\
4 & Company D & $\mathrm{Y}$ & $\mathrm{Y}$ & $\mathrm{N}$ \\
5 & Company E & $\mathrm{N}$ & $\mathrm{N}$ & $\mathrm{Y}$ \\
\hline
\end{tabular}

Entrepreneur $\mathrm{H}$ appraised the situation positively, and sees potential in Pakistan to improve over time. This motivated him to put higher efforts into his business.

In contrast to these two, Entrepreneur F appraised events as having low control potential, which hampered his succession planning because he does not want his children to become a part of the hostile business environment. Entrepreneur $\mathrm{G}$ also appraised the events as having low control potential, and halted business decisions until the next electoral session. Entrepreneur I also appraised the business environment negatively, citing fear and a loss of hope. He is willing to invest more capital in his company, but only for the short-term.

Table 5: Entrepreneurial appraisal summary-Medium performers

\begin{tabular}{clccc}
\hline$\#$ & Company & Appraise positively & Hope & Fear \\
\hline 1 & Company F & $\mathrm{N}$ & $\mathrm{N}$ & $\mathrm{Y}$ \\
2 & Company G & $\mathrm{N}$ & $\mathrm{N}$ & $\mathrm{Y}$ \\
3 & Company H & $\mathrm{Y}$ & $\mathrm{Y}$ & $\mathrm{N}$ \\
4 & Company I & $\mathrm{N}$ & $\mathrm{N}$ & $\mathrm{Y}$ \\
5 & Company J & $\mathrm{Y}$ & $\mathrm{Y}$ & $\mathrm{N}$ \\
\hline
\end{tabular}

\section{- Low performers}

All low performers appraised the events with low control potential resulting in loss of hope. This resulted in a constant fear and hampered the business growth and development plans. Fear and loss of hope caused the shutting down of most of the businesses. Entrepreneur N and Entrepreneur O closed their businesses due to business environment hostility that caused constant mental pressure and stress for them; they saw no signs of improvement. Entrepreneur L, Entrepreneur M, and Entrepreneur K are close to shutting down their businesses, and will not invest further capital. This is primarily because they have no hope of growth in the current hostile environment; they are blinded by fear of terrorism.

Entrepreneur M stated that the main reason for the reversal in his business was the gang war in the area of his sales and operation. Customers simply stopped coming due to an escalation in the gang war. He was pessimistic about his partnership with his brother, which did not work out after the brother stole from the business.

Entrepreneur K stated that law and order affected him a lot. He frequently considered leaving the city, shutting down his business, or relocating somewhere 
else within the city. He became depressed and avoided making purchases to avoid attracting attention leading to extortion calls.

\begin{tabular}{ccccc} 
Table 6: & Entrepreneurial appraisal summary-Low performer \\
\hline$\#$ & Company & $\begin{array}{l}\text { High control } \\
\text { potential }\end{array}$ & Hope & Fear \\
\hline 1 & Company K & $\mathrm{N}$ & $\mathrm{N}$ & $\mathrm{Y}$ \\
2 & Company L & $\mathrm{N}$ & $\mathrm{N}$ & $\mathrm{Y}$ \\
3 & Company M & $\mathrm{N}$ & $\mathrm{N}$ & $\mathrm{Y}$ \\
4 & Company N & $\mathrm{N}$ & $\mathrm{N}$ & $\mathrm{Y}$ \\
5 & Company O & $\mathrm{N}$ & $\mathrm{N}$ & $\mathrm{Y}$ \\
\hline
\end{tabular}

\section{- Analysis}

High performers with self-efficacy and entrepreneurial focus displayed an ability to appraise events with high control potential. They had higher hopes for their business growth. This hope allows them to strategize accordingly, develop business plans, and work towards their attainment. Medium performers demonstrated mixed traits of both high performers and low performers. This highlighted the potential to either move towards success or slump down toward decline. Low performers demonstrated a negative approach towards the situation, which led to fear and a loss of hope. This dampened their ability to create new business goals and strategize future plans.

\subsection{Business strategies}

\subsubsection{High performers}

- Workforce development

One way four high performing companies countered business hostility was by focusing on workforce development. Entrepreneur A of Company A focused on educating and training his workforce. There was only one $\mathrm{PhD}$ in Pakistan in the field of salts, employed as his quality assurance manager.

Company $\mathrm{C}$ focused on developing its executive team, which ensured that members within their departments work at optimal levels. Entrepreneur B2 ensured that Company B only hired educated and experienced personnel who are familiar with their field work and continued to invest further in their grooming through internal training.

Company D focused on developing and training its managers and troubleshooters to ensure smooth running of the company's functions and operations. In contrast to these companies, Entrepreneur E failed to hire efficient people, and did not develop an effective work force through training methods. The company is dependent completely on him, and cannot work without him.

The entrepreneurs of four of the companies did not face the threats directly; they addressed them through their executives. Entrepreneur A of Company A 
trained his executives to face threats directly. Entrepreneur E did not have any executives or managers around him and is currently exposed to direct threats; he was almost kidnapped and receives extortionist calls directly on his phone.

- Innovation and new products

Focusing on R\&D is another tool for businesses to employ to counter environmental hostility. Four out of five high performing companies did exactly this. Their focus was on R\&D and innovation. Company A discovered industrial uses of salt through $\mathrm{R} \& \mathrm{D}$, and expanded the company that way. Company $\mathrm{C}$ had a separate $R \& D$ facility in India that helps innovate and cater to its target audiences. Company B relied on market studies and research to ensure that it meets consumer needs. Company D also relied on information from clients and partners to ensure that it meets consumer needs and demands. Company E, in contrast to these firms, did not employ any $R \& D$ and is succeeding only because of lack of competition in the local market.

- Insulate the leader from threats

Three of the five high performing companies insulated the leadership from threats. For example, the real ownership of Company C is not known. Similarly, business leaders of companies like Company B and Company D avoid social interactions with the press. In contrast, Entrepreneur A of Company A is a popular figure, and is widely known. He is accessible and approachable; however, Entrepreneur A has built a team which takes care of day to day operations and Entrepreneur A mainly focuses on building networks and strategic alliances. Entrepreneur E is also a known figure but has no management or work force surrounding him and giving support.

- Paying taxes

Paying taxes and keeping the tax authorities happy is a strategy that has worked well for these entrepreneurs. Company B is among the higher tax paying corporate entities with a transparent accounting system. Company D is also among the top 100 tax paying corporate entities. Most of the high performing entrepreneurs pride themselves on being top tax payers in Pakistan. However, they also pointed out that paying high tax gives them leverage over the tax authorities and other regulators; these agencies and regulators are dependent on their companies to meet their own budgetary targets.

The only exception is Company E. For a majority of its sales, it stays outside the tax net. Therefore, most of its capital is stuck in the market as receivable.

\section{- Value of the company}

Building intrinsic value of the company through tangible and intangible assets helped entrepreneurs counter business hostility. Company B focused on developing its brand equity. Company $\mathrm{C}$ observed that its uniquely composed products were the most valuable assets for the company. Company D developed the company's value by obtaining international licenses for products for the local market. Company A developed intrinsic value through internal knowledge development and $\mathrm{R} \& \mathrm{D}$ regarding salt. Company $\mathrm{E}$ developed value for the company through client relations and a more flexible credit cycle, compared to other industrial players. 
- National reach

All high performers had a national reach, distribution channels and agents across the country to cater to clients from all areas.

- Export/ International partnerships

International linkages and connections helped four out of five companies in this category to counter the effects of business hostility on their business. Company B launched retail outlets in the Middle East and Malaysia. Company A and Company $\mathrm{C}$ have foreign markets for their products. Company D has contracts with foreign companies that help authenticate its position in the local market. Company E, in contrast, relies only on national sales for its products and has no international linkages.

- Quality and excellence

Quality maintenance and excellence is another strategy through which firms countered business environment hostility. Entrepreneur A maintained focus on quality to ensure that it works with the top clients in the market. Entrepreneur E maintained a focus on quality of products to ensure higher margins. Company $\mathrm{C}$ tried to incorporate international standards in its production processes to ensure quality, and is the only company in Pakistan to offer product liability insurance. Company D focused internally to improve the quality of its products. Similarly, Company B hired various specialists in different fields to ensure that its products and processes are of high quality.

Table 7: Business Strategies: Summary-High performers

\begin{tabular}{|c|c|c|c|c|c|}
\hline Company A & Company B & Company C & Company D & Company E & $\begin{array}{l}\text { Business } \\
\text { strategy }\end{array}$ \\
\hline $\begin{array}{l}\text { W.F.D. Exec- } \\
\text { utives }\end{array}$ & $\begin{array}{l}\text { W.F.D. Exec- } \\
\text { utives }\end{array}$ & $\begin{array}{l}\text { W.F.D. Ex- } \\
\text { ecutives }\end{array}$ & $\begin{array}{l}\text { W.F.D. Man- } \\
\text { agers }\end{array}$ & No & W.F.D. \\
\hline $\mathrm{R} \& \mathrm{D}$ & No & $\mathrm{R} \& \mathrm{D}$ & No & No & $\mathrm{R} \& \mathrm{D}$ \\
\hline $\begin{array}{l}\text { Leader engag- } \\
\text { ing }\end{array}$ & $\begin{array}{l}\text { Leader insu- } \\
\text { lated }\end{array}$ & $\begin{array}{l}\text { Leader insu- } \\
\text { lated }\end{array}$ & $\begin{array}{l}\text { Leader insu- } \\
\text { lated }\end{array}$ & $\begin{array}{l}\text { Leader ex- } \\
\text { posed }\end{array}$ & Leadership \\
\hline Paying taxes & Paying taxes & Paying taxes & Paying taxes & No & $\begin{array}{l}\text { Paying } \\
\text { taxes }\end{array}$ \\
\hline $\begin{array}{l}\text { Knowledge of } \\
\text { product }\end{array}$ & Brand & $\begin{array}{l}\text { Unique } \\
\text { molecules } \\
\text { qwnership }\end{array}$ & $\begin{array}{l}\text { Sole dist \& } \\
\text { Man }\end{array}$ & Capital int & Comp val \\
\hline Nat reach & Nat reach & Nat reach & Nat reach & Nat reach & Nat reach \\
\hline Export/Int & Export/Int & Export/Int & Export/Int & None & \\
\hline $\begin{array}{l}\text { Quality \& Ex- } \\
\text { cellence }\end{array}$ & Quality & $\begin{array}{l}\text { Quality \& } \\
\text { Excellence }\end{array}$ & Excellence & Quality & $\begin{array}{l}\text { Customer } \\
\text { oriented }\end{array}$ \\
\hline
\end{tabular}

\subsubsection{Medium performers}

- Workforce development

Two of the five medium performing companies focused on development of a team and effective workforce. Realizing its importance to success, Mustafa Rahman 
developed a team of close colleagues that he trusts with internal tasks of the company. Entrepreneur $\mathrm{H}$ focused on team development to succeed at higher levels. In contrast, Entrepreneur G, Entrepreneur I, and Entrepreneur F run all functions and operations of their businesses themselves, and did not focus on developing a team or a workforce for their business.

- Placement within the value chain

Placement of the company based on its products and strengths within the value chain is an important determinant of success. Company G, Company I, and Company $\mathrm{F}$ are suppliers to manufacturing-based industrial clients. Company $\mathrm{H}$ supplies textile products to international companies that further process them. Company $\mathrm{J}$, in contrast, supplies directly to end consumers through distributors and various retail channels.

- Client diversity

Company J, Company H, and Company I supply their products to national and international clients, bringing in a diversity of clientele and varying sources of revenue generation. In contrast, Company $\mathrm{G}$ focuses only on clients and markets in South Pakistan, Sindh and Baluchistan. Similarly, Company F focuses only on clients and markets in Karachi, which restricts client diversity and revenue chains for these companies.

- New product development

Four of the five companies focused on developing new products and on innovation to counter business hostility and grow their businesses. Entrepreneur G meets his clients regularly, which helps him identify gaps in the market. Entrepreneur I and Entrepreneur $\mathrm{H}$ have strong client relations, which helps them gauge client demands and requirements. Mustafa Rahman developed a strong R\&D division that identifies market trends and consumer behavior to design better placement and promotion tactics for his products. In contrast, Entrepreneur F does not want further investment in his business, and will not pursue expansion through new product development.

- Strength of the company

Medium performing companies countered business hostility by developing their strengths. Entrepreneur $\mathrm{H}$ focused on his company's production and financial efficiencies. Entrepreneur I focused on client relations to leverage his products. Similarly, Entrepreneur G focused on production capacities, maintaining and increasing them to meet client demands. Entrepreneur J focused on building brand equity and awareness through different product lines. Lastly, Entrepreneur F focused on maintaining quality and consistency to renew manufacturing licenses from an American brand for hangers.

\subsubsection{Low performers}

- Family partnerships 
Entrepreneurial cognition process ...

Table 8: Business Strategies: Summary-Medium performers

\begin{tabular}{|c|c|c|c|c|c|}
\hline Company $\mathrm{H}$ & Company G & $\begin{array}{l}\text { Company } \\
\text { F }\end{array}$ & Company $\mathrm{J}$ & Company I & $\begin{array}{l}\text { Business } \\
\text { strategy }\end{array}$ \\
\hline $\begin{array}{l}\text { W.F.D.- } \\
\text { Executives }\end{array}$ & $\begin{array}{l}\text { W.F.D.- } \\
\text { Managers }\end{array}$ & $\begin{array}{l}\text { Production } \\
\text { labor }\end{array}$ & $\begin{array}{l}\text { Production } \\
\text { labor }\end{array}$ & $\begin{array}{l}\text { Production } \\
\text { labor }\end{array}$ & W.F.D. \\
\hline $\begin{array}{l}\text { Supplier to } \\
\text { industry }\end{array}$ & $\begin{array}{l}\text { Supplier to } \\
\text { industry }\end{array}$ & $\begin{array}{l}\text { Supplier to } \\
\text { industry }\end{array}$ & $\begin{array}{l}\text { Supplier to } \\
\text { retail }\end{array}$ & $\begin{array}{l}\text { Supplier to } \\
\text { industry }\end{array}$ & $\begin{array}{l}\text { Placement } \\
\text { within value } \\
\text { chain }\end{array}$ \\
\hline National/Int & $\begin{array}{l}\text { South Pak- } \\
\text { istan }\end{array}$ & $\begin{array}{l}\text { Karachi } \\
\text { based } \\
\text { industries }\end{array}$ & National/Int & National/Int & $\begin{array}{l}\text { Client diver- } \\
\text { sity }\end{array}$ \\
\hline $\begin{array}{ll}\text { Based } & \text { on } \\
\text { industry } & \\
\text { trends- } & \\
\text { Follower } & \end{array}$ & $\begin{array}{l}\text { Based on } \\
\text { customer } \\
\text { needs- } \\
\text { Active }\end{array}$ & None & $\begin{array}{lr}\text { R\&D } & \& \\
\text { market gap } \\
\text { identification- } \\
\text { Active }\end{array}$ & $\begin{array}{l}\text { Based on cus- } \\
\text { tomer needs- } \\
\text { Follower }\end{array}$ & $\begin{array}{l}\text { New product } \\
\text { development }\end{array}$ \\
\hline $\begin{array}{l}\text { Volume/Diverse } \\
\text { clientele }\end{array}$ & $\begin{array}{l}\text { Volume/Prod } \\
\text { range/Client } \\
\text { relations }\end{array}$ & $\begin{array}{l}\text { Licensed } \\
\text { brand }\end{array}$ & $\begin{array}{l}\text { Brand/Product } \\
\text { range }\end{array}$ & $\begin{array}{l}\text { Volume/Client } \\
\text { relations }\end{array}$ & $\begin{array}{l}\text { Strength of } \\
\text { the company }\end{array}$ \\
\hline
\end{tabular}

Family involvement led to low performance for the entrepreneurs in this study. Business leaders struggled to terminate non-performing employees who were also family members. Entrepreneur $\mathrm{K}$ admitted to having his brother resist hiring of new resources. Company $\mathrm{L}$ has family politics to blame for its demise. The father was not interested in business expansion, and the business greatly suffered. Entrepreneur M of Company M blamed his brother for siphoning off the business earnings and investing it in personal property. Entrepreneur $\mathrm{O}$ of Company $\mathrm{O}$ claimed that the partnership among his seven brothers resulted in lower accountability and reduced motivational levels.

- Lack of innovation

A key to survivability in business is innovation. Low performers failed to innovate and became complacent in their success. Company $\mathrm{M}$ gained instant success, but continued producing tea using primitive methods that others copied. Entrepreneur $\mathrm{N}$ failed to upgrade his factory with the latest machinery and equipment, and his competitors out-paced him with latest technology in international markets. Entrepreneur K of Company K and Entrepreneur L of Company L reported that anyone with capital can import technology from China and pose threat to their business models. Entrepreneur O admitted that old technology defeated new technology in aluminum recycling; old plants operated on low costs and with less permanent staff.

- Non-conducive industry practices

Non-conducive industry practices resulted in low performance. There is always a threat of credit turning into bad debt. There is uncertainty as to when clients owing large sums may declare default. Entrepreneur N of Company N stated that there is no point in manufacturing an item that will not be paid for by its purchasers. Bad credit and delayed payments was the primary reason for Entrepreneur O to shut down his operations. Company L and Company M also cited their capital being stuck with the clients as a major concern. They had to employ recovery agents, which distracted from the growth of the business.

Business Review: (2019) 14(2):92-115 


\section{- Competition}

The presence of large market players subdues chances of success for other businesses. At times, large industry players lobby the government to change policies conducive to their needs rather than the market needs, according to Entrepreneur O. These agencies allow smuggled raw materials to drive down their prices and beat the competition. Entrepreneur K admitted to being part of a cartel that controlled the prices of products. Such practices provide leverage to the market players. Company $M$ was surpassed by Tapal as a strong brand backed by an immense marketing team and supply chain.

- Partnerships

Wrong partnerships resulted in failure for some companies. Company M's downfall resulted due to a mismatch in the partnership of brothers; one partner secretly siphoned profits and reported the company to tax authorities for fraud. A similar situation arose with Entrepreneur L; the partners disputed the takeover of the company, distracting from business growth. In the case of Company K, the partners were at a skill level mismatch; one was uneducated but understood the production process. Entrepreneur O admitted to entering the partnership to lessen his overall burden, but it ended up being a drag on the company.

- Limited social network

Entrepreneur K admitted to distractions from the hostile environment to the extent that he never had any interest in developing social business relations. Entrepreneur M and Entrepreneur L did not mention being part of any cartel or social network for expanding their businesses. Their contacts were limited to the extent that Entrepreneur $\mathrm{M}$ was unable to place his son in a decent job elsewhere. Entrepreneur L was so upset by his surroundings that he changed his dress based on the social environment to avoid undue attention. Entrepreneur $\mathrm{O}$ was dependent on his partner to develop connections, which proved futile. The only entrepreneur in this category who was part of a big network was Entrepreneur $\mathrm{N}$ of Company $\mathrm{N}$ who represents his tribal community and textile mill owners.

\section{- Distracted ambitions}

Low performing entrepreneurs were either engaged or want to engage in other activities. With a lack of clear goals and mission, they hampered business growth. Entrepreneur $M$ was involved in soap manufacturing and tea manufacturing with his brother. Similarly, Entrepreneur L continued to learn diverse skills and work in various fields (e.g., stones and artificial jewelry). Entrepreneur K wanted to enter the real estate industry. Entrepreneur $\mathrm{N}$ was involved in agriculture, manufacturing, and trading in other areas. Entrepreneur $\mathrm{O}$ is now working in real estate and construction.

- Brand development

Two of the entrepreneurs in this category tried to distinguish themselves within the market by developing a specific brand of products. The other three did not think of developing any brand for their product line. 
Entrepreneurial cognition process ...

Table 9: Business strategies: Summary-Low performers

\begin{tabular}{|c|c|c|c|c|c|}
\hline Company K & Company L & Company M & Company N & Company O & $\begin{array}{l}\text { Failed strate- } \\
\text { gies }\end{array}$ \\
\hline Yes & Yes & Yes & Yes & Yes & Initial success \\
\hline $\begin{array}{l}\text { Brother dis- } \\
\text { tracted }\end{array}$ & $\begin{array}{l}\text { Father dis- } \\
\text { tracted }\end{array}$ & $\begin{array}{l}\text { Brother } \\
\text { stole }\end{array}$ & $\begin{array}{l}\text { Family busi- } \\
\text { ness }\end{array}$ & $\begin{array}{l}\text { Brother dis- } \\
\text { tracted }\end{array}$ & Family \\
\hline $\begin{array}{l}\text { Old tech- } \\
\text { nology }\end{array}$ & $\begin{array}{l}\text { Old tech- } \\
\text { nology }\end{array}$ & $\begin{array}{l}\text { Old tech- } \\
\text { nology }\end{array}$ & $\begin{array}{l}\text { Old technol- } \\
\text { ogy }\end{array}$ & $\begin{array}{l}\text { Old technol- } \\
\text { ogy }\end{array}$ & Innovation \\
\hline Credit & Credit & Credit & Credit & Credit & $\begin{array}{l}\text { Bad industry } \\
\text { practice }\end{array}$ \\
\hline Big players & $\begin{array}{l}\text { Many play- } \\
\text { ers }\end{array}$ & Big players & $\begin{array}{l}\text { Many play- } \\
\text { ers }\end{array}$ & Big players & $\begin{array}{l}\text { Industry sat- } \\
\text { urated }\end{array}$ \\
\hline $\begin{array}{l}\text { Wrong part- } \\
\text { ners }\end{array}$ & $\begin{array}{l}\text { Wrong part- } \\
\text { ners }\end{array}$ & $\begin{array}{l}\text { Wrong } \\
\text { partners }\end{array}$ & Not Known & $\begin{array}{l}\text { Wrong part- } \\
\text { ners }\end{array}$ & Partnerships \\
\hline Limited & $\begin{array}{l}\text { Non- } \\
\text { Existent }\end{array}$ & $\begin{array}{l}\text { Non- } \\
\text { Existent }\end{array}$ & Present & $\begin{array}{l}\text { Non- } \\
\text { Existent }\end{array}$ & $\begin{array}{l}\text { Social net- } \\
\text { work }\end{array}$ \\
\hline Real estate & Real estate & Real estate & Trading & Trading & $\begin{array}{l}\text { Distracted } \\
\text { ambitions }\end{array}$ \\
\hline Developed & $\begin{array}{l}\text { Did not de- } \\
\text { velop }\end{array}$ & Developed & $\begin{array}{l}\text { Did not de- } \\
\text { velop }\end{array}$ & $\begin{array}{l}\text { Did not de- } \\
\text { velop }\end{array}$ & Brand \\
\hline
\end{tabular}

\section{Practical implications for entrepreneurs and business managers}

Based on the results of this research, it seems that there are many specific approaches an entrepreneur can take to become successful in the hostile business environment. How the entrepreneurs conceptualized the hostile environment was the basis of the response strategies that each of the 15 entrepreneurs devised for their firms. High performers conceptualized the hostile environment in such a way that it was a solvable problem. Four of the five entrepreneurs of the successful firms found a way to stay focused on the firm and the business. They made it part of their strategy to avoid the noise and distraction which the turbulent and violent environment presented.

Eight out of fifteen entrepreneurs demonstrated self-efficacy within the hostile environment. All eight belonged to either the high performer or medium performer category. Uncertainty was present for those entrepreneurs in this study who did not have clear succession planning for the firm. Continuous improvement, not a rapid response to the events or threats by the environment, was essential for high performance. The entrepreneurs who were able to maintain focus had a relevant workforce that insulated the entrepreneur and qualified executives who dealt with threats. Holding patterns or wait and see strategies are more likely adopted by entrepreneurs who appraise the events with low control potential and belong to the medium and low performer categories.

\section{Conclusion}

Based on the results, researchers found that the hostile business environment includes terrorism/violent crimes for entrepreneurs. Based on comparison of the three categories (high performers, medium performers, and low performers), researchers suggest there is a clear difference between the conceptualization of 
the hostile business environment by the entrepreneurs and their entrepreneurial cognition process within the hostile environment. Researchers found that entrepreneurs who maintain focus, have self-efficacy, and pursue a higher level of education within the hostile business environment are more likely to appraise situations as within their control and take actions to counter variables that create the hostile environment for their businesses. One of the most successful business strategies is development/retention of a vibrant workforce. Through this relevant workforce (specific strategy), the entrepreneurs insulate themselves and their business operations from direct threats from the hostile environment. This helps them maintain their focus on the business.

In the course of this study, it was identified that workforce development, succession planning and conceiving problems as solvable (optimism) are prerequisites for entrepreneurial orientation (Miller and Friesen 1983). With the help of these, successful entrepreneurs remove uncertainty from the environment. It results in enhanced self-efficacy and retains focus on objectives of the firm and future planning, giving rise to characteristics of entrepreneurial orientation i.e. innovation, proactiveness and risk-taking.

\section{References}

Abadie A, Gardeazabal J (2008) Terrorism and the world economy. European Economic Review 52(1):1-27

Acs ZJ, Audretsch DB (2006) Handbook of entrepreneurship research: An interdisciplinary survey and introduction, vol 1. Springer Science \& Business Media

Adeoye AO, Elegunde AF (2012) Impacts of external business environment on organisational performance in the food and beverage industry in nigeria. British Journal of Arts and Social Sciences 6(2):194-201

Adomako S, Danso A (2014) Regulatory environment, environmental dynamism, political ties, and performance: Study of entrepreneurial firms in a developing economy. Journal of Small Business and Enterprise Development 21(2):212-230

Ansoff HI (1987) The emerging paradigm of strategic behavior. Strategic management journal $8(6): 501-515$

Arieftiara D, Utama S, Wardhani R (2017) Environmental uncertainty as a contingent factor of business strategy decisions: Introducing an alternative measure of uncertainty. Australasian Accounting, Business and Finance Journal 11(4):116-130

Bandura A (1999) Social cognitive theory: An agentic perspective. Asian journal of social psychology 2(1):21-41

Bandura A (2012) On the functional properties of perceived self-efficacy revisited

Bingham CB, Eisenhardt KM, Furr NR (2011) Which strategy when. MIT Sloan Management Review 53(1):71-77

Brews P, Purohit D (2007) Strategic planning in unstable environments. Long Range Planning 40(1):64-83

Campos HM, Parellada FS, Valenzuela FAA, Rubio AM (2015) Strategic decision-making speed in new technology based firms. RAI Revista de Administração e Inovação 12(2):130 152

Courtney H, Kirkland J, Viguerie P (1997) Strategy under uncertainty. Harvard business review 75(6):67-79

Covin JG, Slevin DP (1989) Strategic management of small firms in hostile and benign environments. Strategic management journal 10(1):75-87

Davis D, Morris M, Allen J (1991) Perceived environmental turbulence and its effect on selected entrepreneurship, marketing, and organizational characteristics in industrial firms. Journal of the Academy of Marketing Science 19(1):43-51

Eruemegbe GO (2015) Impact of business environment on organization performance in nigeriaa study of union bank of nigeria. European Scientific Journal 
Gartner B (1989) Who is an entrepreneur is the wrong question? advances in entrepreneurship. Summer

Goktan AB, Gunay G (2011) Is entrepreneurial cognition culturally bound? a comparative study conducted in turkey and the united states. Journal of Small Business \& Entrepreneurship 24(4):455-470

Haj-Yehia S (2003) Terrorizing the consumers and investors. Unpublished paper, Massachusetts Institute of Technology

Hall WK (1980) Survival strategies in a hostile environment. Harvard Business Review 58(5):75-85

Khandwalla PN (1972) Environment and its impact on the organization. International studies of management \& organization 2(3):297-313

Kotey B, et al (2014) Small business innovation in the hostile environment of australia's drought stricken rural communities. Australasian Journal of Regional Studies, The 20(2):325

Lawton T, Rajwani T, Reinmoeller P (2012) Do you have a survival instinct? leveraging genetic codes to achieve fit in hostile business environments. Business Horizons 55(1):8191

Lindelöf P, Löfsten H (2006) Environmental hostility and firm behavioran empirical examination of new technology-based firms on science parks. Journal of Small Business Management 44(3):386-406

Miller D, Friesen PH (1983) Strategy-making and environment: the third link. Strategic management journal 4(3):221-235

Mitchell RK, Busenitz L, Lant T, McDougall PP, Morse EA, Smith JB (2002) Toward a theory of entrepreneurial cognition: Rethinking the people side of entrepreneurship research. Entrepreneurship theory and practice 27(2):93-104

Peng MW (2001) How entrepreneurs create wealth in transition economies. Academy of Management Perspectives 15(1):95-108

Popescu S (2014) Controllable and uncontrollable variables in the study of entrepreneurship, in small and medium business. International Review of Management and Business Research $3(2): 762$

Prieto-Rodríguez J, Rodríguez JG, Salas R, Suarez-Pandiello J (2009) Quantifying fear: The social impact of terrorism. Journal of Policy Modeling 31(5):803-817

Shrivastava P (2005) Managing risks in the age of terror. Risk Management 7(1):63-70

Steensma HK, Marino L, Weaver KM, Dickson PH (2000) The influence of national culture on the formation of technology alliances by entrepreneurial firms. Academy of management journal 43(5):951-973

Torkkeli L, Puumalainen K, Saarenketo S, Kuivalainen O (2012) The effect of network competence and environmental hostility on the internationalization of smes. Journal of International Entrepreneurship 10(1):25-49

Vagnoni E, Khoddami S (2016) Designing competitivity activity model through the strategic agility approach in a turbulent environment. foresight 18(6):625-648

Wernerfelt B, Karnani A (1987) Competitive strategy under uncertainty. Strategic Management Journal 8(2):187-194

Wong PK, Ho YP, Autio E (2005) Entrepreneurship, innovation and economic growth: Evidence from gem data. Small business economics 24(3):335-350

Zhang M (2010) Entrepreneurial discovery in a transitional economy: China 1979-2009. In: Proceedings of the 5th European Conference on Innovation and Entrepreneurship, p 700 